\title{
Анализ деятельности по управлению градостроительным процессом в Москве нач. XVIII - конца XX века
}

\author{
С.О.Кузнецов, Комитет по архитектуре и градостроительству города Москвы, МАРХИ, Москва
}

Градостроительный процесс во всём мире, в том числе и в России, носит стадиальный характер, который означает, что этапы активного развития чередуются с фазами замедления. Историков архитектуры всегда интересовали факторы, влиявшие на смену этапов, и вопросы периодизации градостроительства. Одним из важнейших факторов, влиявших на стадиальность градостроительного развития, является организация системы управления градостроительным процессом. Особенно ярко это проявилось в Москве вследствие её уникального положения в иерархии российских городов, особой исторической важности для императоров и политических лидеров государства, изменениям столичного административного статуса, а также вызовов, связанных с антропогенными и природными катаклизмами.

История создания и развития структур и механизмов управления градостроительством Москвы началась около трёхсот лет назад, и сама по себе является ценным элементом градостроительной культуры. В статье предпринята попытка с позиции ретроспективного анализа выявить этапы эволюции, их закономерности и различия, разобраться в механизмах выработки решений и взаимодействия субъектов системы управления градостроительным процессом в Москве на протяжении длительного исторического периода: с момента переноса столицы в Санкт-Петербург в 1713-1714 годад до возвращения ей столичного статуса в 1918-ом и затем - до превращения в столицу СССР, а затем-Российской Федерации (1991). Это историческое знание полезно как для понимания градостроительного процесса Москвы, так и для создания эффективной модели управления градостроительным развитием в будущем.

Ключевые слова: генеральный план, главный архитектор Москвы, градостроительное развитие, градостроительство Москвы, Москва, управление градостроительным процессом.

\section{The Analysis of Activities for the Management of the Urban Development Process in Moscow at the Beginning of the XVIII - late XX century}

S.0.Kuznetsov, Committee for Architecture and Urban Planning of Moscow, MArchI, Moscow

Urban development throughout the world, including Russia, occurs in stages, eras of active development alternating with stages of slowdown or even stagnation. Historians of architecture have had a longstanding interest in the periodization, factors, and events that influence these stages. Conscious attempts to manage urban and architectural development has been, historically, one of the most important influences on the course of urban construction and growth. This has been especially true in the case of Moscow, given its unique position within the hierarchy of Russian cities and its changing status as an administrative capital.

Systematic attempts to develop the structures and mechanisms of urban management go back at least 300 years in Moscow and have had a strong influence on the city's urban and cultural history. This article offers a timeline and a retrospective analysis of the stages of urban planning in Moscow over the longue durée, from the moment the capital was transferred to St. Petersburg in 1713-1714 until it regained its capital status in 1918, and then until it was transformed from the capital of the Union of the Socialist Republics into the capital of the Russian Federation (1991).

Keywords: master plan, chief architect of Moscow, urban development, urban development of Moscow, Moscow, management of the urban development process.

Градостроительный процесс в России, как и во всем мире, происходит неравномерно, проходя через стадии быстрого развития и замедления. Неудивительно, что факторы, влияющие на градостроительное развитие, а также вопросы его периодизации всегда интересовали исследователей. Существуют разные варианты периодизации истории градостроительства, обусловленные наиболее важными для каждого конкретного исследования критериями, к примеру - смена общественноэкономических формаций [1]; смена архитектурных стилей [2]; конкурсное проектирование как движущий фактор градостроительства [3] и др. Одним из важнейших факторов, влияющих на смену этапов градостроительного развития, служит организация системы управления градостроительным процессом. Она представляет ценность сама по себе как неотьемлемая часть градостроительного наследия. Влияние этого фактора исключительно ярко проявилось в Москве, которая в силу целого ряда причин является идеальным объектом исследования. К ним относятся уникальное положение Москвы в иерархии российских городов как исторического, экономического и политического центра страны; лишение в XVIII веке и возвращение в XX веке статуса административной столицы; повышенное внимание правителей государства - императоров и политических лидеров; изменения столичного административного статуса, а также вызовы, связанные с антропогенными 
и природными катаклизмами: пожарами, эпидемиями, войнами. Под системой управления градостроительным процессом нами понимается согласованность действий взаимосвязанных субъектов и их элементов, обеспечивающее выполнение задач управления. К ним относятся: административные органы и должности, коммуникативные механизмы взаимодействия между элементами системы, методы и инструменты управления, как, например, генеральные планы, планы развития или реконструкции города [4].

Десятилетие 1730-х годов стало временем подготовки к активным градостроительным мероприятиям 1742-1762 годов и первой фазой активного систематического управления градостроительным процессом.

Эта фаза соответствует времени правления императрицы Елизаветы Петровны (1742-1761), которая часто и надолго наезжала в Москву. Указом 1742 года Елизавета Петровна учредила при Московской полицмейстерской канцелярии должность архитектора с шестью помощниками «для регулирования в Москве улиц и для строения обывателям по большим и малым улицам разного строения». В обязанности городского архитектора и его помощников входили планировка улиц, кварталов и составление планов владений ${ }^{1}$ [5, с. 282]. Тем самым было начато формирование системы управления градостроительным процессом в Москве, в основе которой была государственная воля императрицы, осуществляемая в деятельности архитектора Дмитрия Васильевича Ухтомского. В литературе его нередко называют первым главным архитектором Москвы [1, с. 129; 5, с. 17] (рис. 1).

В течение двадцатилетнего пребывания на посту московского архитектора (1742-1762) Ухтомский спроектировал и осуществил целый ряд проектов, которые свидетельствовали о градостроительном подходе к проектированию города. После пожаров 1748-1752 годов Д.В. Ухтомский составил планы новой застройки [5, с. 296, 319].

Второй этап эволюции управления градостроительным процессом в Москве (1762-1813) также состоял из фаз подъёма и стагнации. Годы с 1762-го по начало 1770-х есть основания считать «пассивной» фазой управления и временем подготовительной фазы для нового скачка развития. После смерти Елизаветы Петровны и увольнения Д.В. Ухтомского с должности городского архитектора в 1762 году градостроительная активность в древней столице снизилась. Функцией архитекторов при Полицмейстерской канцелярии была выдача разрешений на строительство. Императрица Екатерина II (годы правления: 1761-1796) в шестидесятых годах XVIII века затеяла фундаментальную реформу управления городом и городским планированием. В Москве фактическим толчком для срочных мер реконструкции послужили пожары и эпидемии 1771-1773 годов, опустошившие город.

Вторая, «активная» фаза управления градостроительным процессом рассматриваемого этапа началась в 1774 году: для

${ }^{1}$ ПСЗ. - Собр. 1-е. - СПб., 1830. - Том 11. - № 8556. - С. 602-603. восстановления Москвы по приказу императрицы были созданы своего рода «чрезвычайные» органы управления: сначала «0собый департамент Комиссии о каменном строении», который подготовил проект реконструкции и предложения о создании «Каменного приказа», а затем - Каменный приказ (рис. 2). П.Н. Кожин, назначенный из Петербурга руководить восстановлением города, возглавил оба учреждения [7, с. 150-156; 5, с. 102-107] (рис. 3). Главным архитектором Особого департамента, а затем и Каменного приказа, назначили представителя французского классицизма Николу Леграна. Он принимал деятельное участие не только в разработке «генерального плана» города, но и отвечал за проектирование новых кварталов [8, с. 141]. Подготовленные документы императрица рассматривала лично. Не сработавшись с П.Н. Кожиным, Н. Легран в 1778 году вынужден был просить об увольнении. Из-за разногласий между московской полицией и руководством Каменного приказа работа последнего оказалась малоэффективной [7, с. 169]. В 1782 году приказ был упразднён; вместо Полицмейстерской канцелярии учреждена Управа благочиния во главе с обер-полицмейстером. К ней перешли все функции строительного регулирования:учёт квартир под постой, соблюдение противопожарныхтребований и утверждение планов и фасадов обывательских строений [9, с. 98, 99, 147-151].

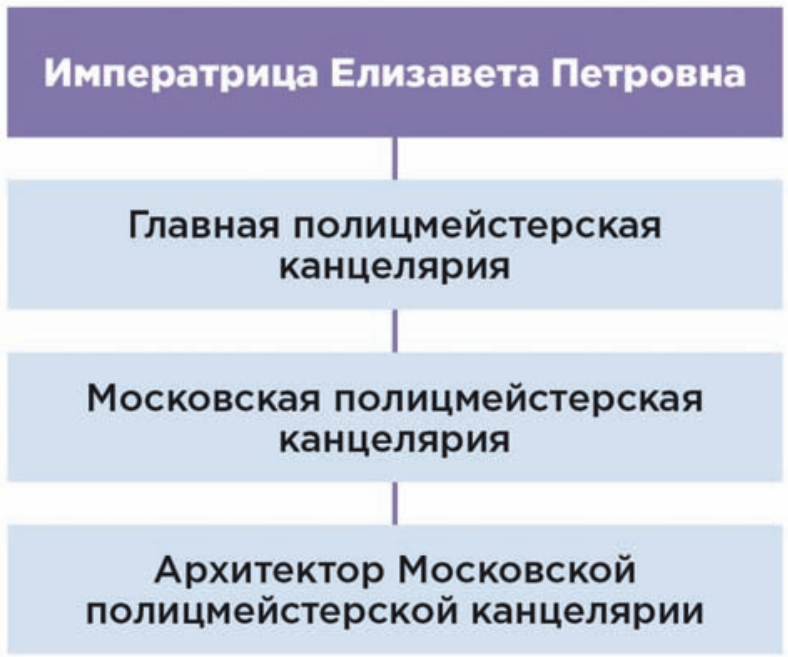

Рис. 1. Схема управления архитектурно-градостроительным процессом Москвы в 1742-1762 годы

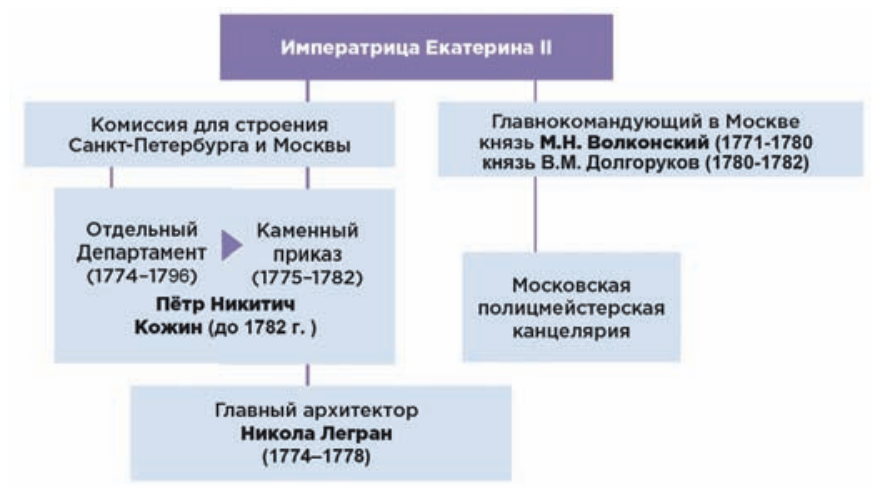

Рис. 2. Схема управления архитектурно-градостроительным процессом Москвы в 1775-1782 годы 

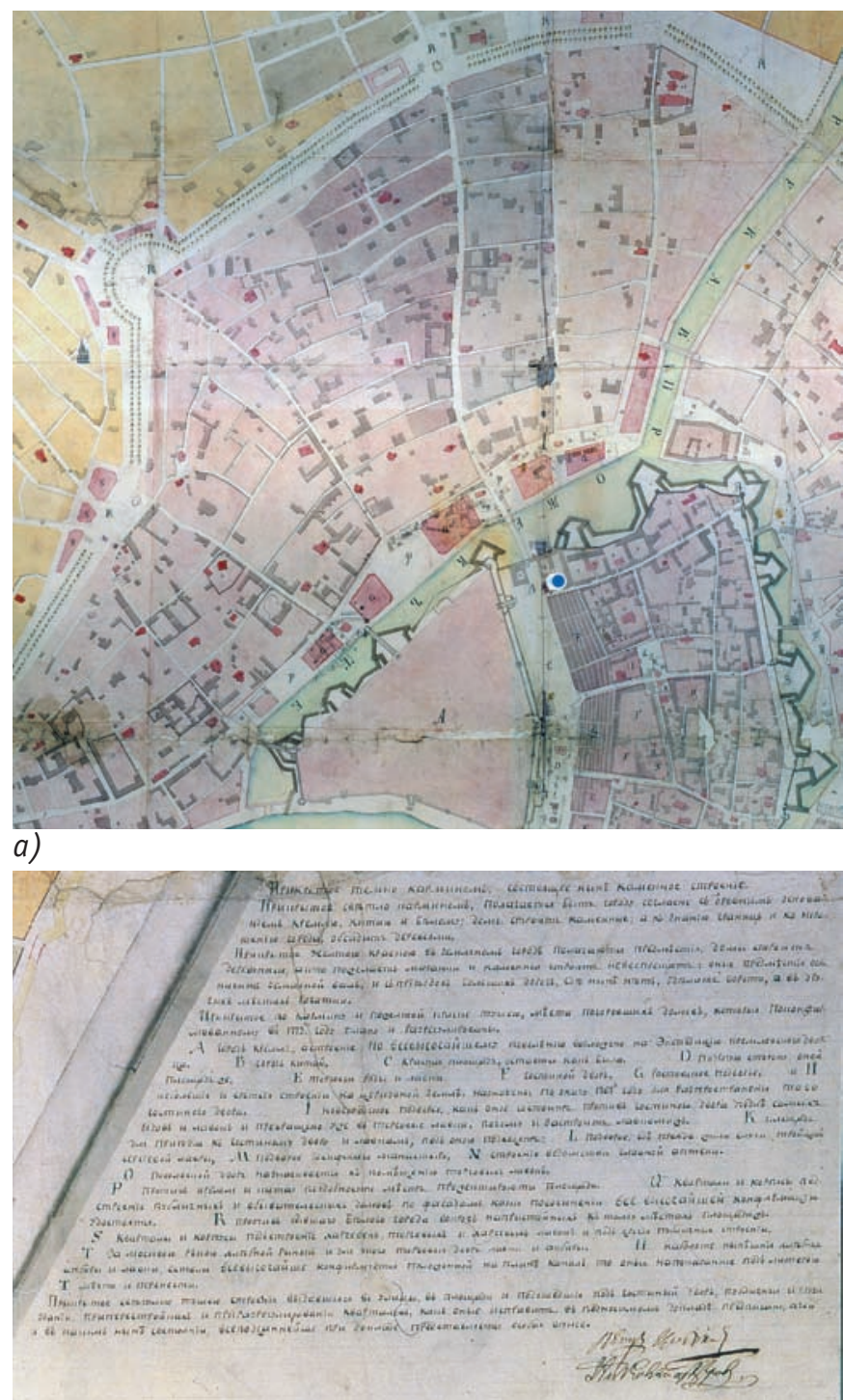

б)

Рис. 3. «Прожектированный» план Москвы 1775 г.: а) фрагмент плана Москвы.; б) экспликация с описанием предполагаемых строений

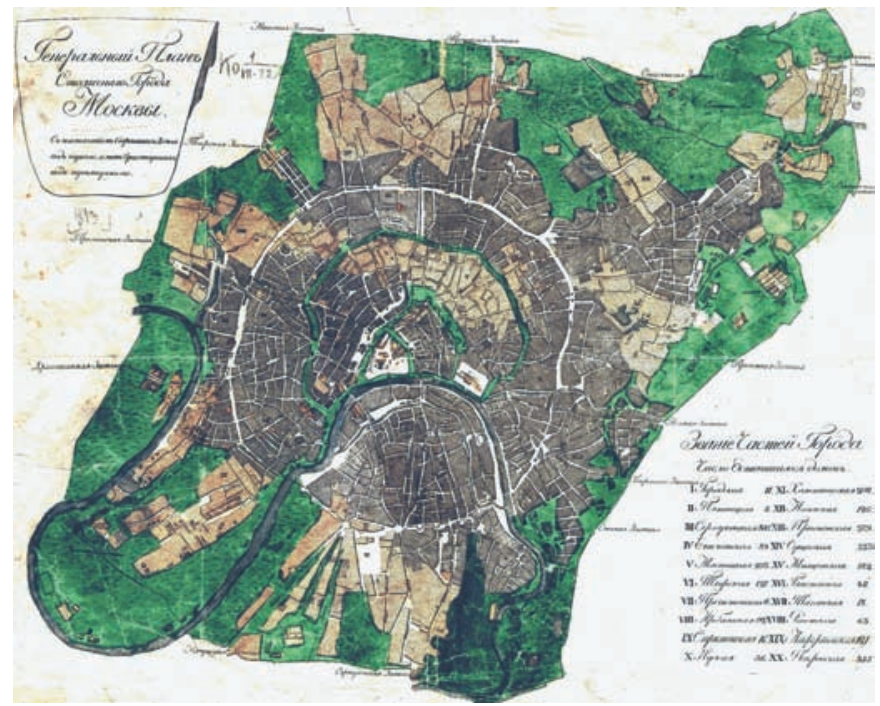

Рис. 4. План Москвы споказанием сгоревших строений. 1813 год
После 1782 года в управлении московским градостроительным процессом наступила фаза стагнации, продолжавшаяся до 1812 года Во второй половине 1780-х годов сменявшие друг друга главнокомандующие Москвы - А.Я. Брюс, П.Д. Еропкин, А.А Прозоровский - попытались провести реконструкцию центра Москвы в соответствии с намеченными ранее планами. В эти годы шла расчистка стен Белого города и укреплений Земляного города, однако несмотря на требования Екатерины II придерживаться утверждённого плана, вместо запроектированных бульваров и площадей происходило быстрое заполнение освобождавшихся участков стихийной застройкой. А.А Прозоровский в 1791 году признавал, что «высочайше конфирмованного плана городу Москве выполнить невозможно» [9, с. 302]. После смерти Екатерины II и эти усилия сошли на нет.

Третий этап эволюции управления градостроительным развитием Москвы начался в 1813 году сразу после жестокого пожара, вызванного нашествием наполеоновской армии, и завершился в начале 1860-х годов (рис. 4). По смыслу происходящих процессов этот этап можно разделить на три фазы - активной деятельности по управлению градостроительным процессом (1813-1834), фазу замедления процессов управления (1834-1843) и фазу стагнации (1843 - нач. 1860-х).

В огне московского пожара 1812 года погибло более 70 процентов городской застройки. Император Александр II «по соболезнованию к <...> обывателям Московской столицы» распорядился о выделении финансовой помощи и создании комиссии для реконструкции города. 1813-1834 годы стали весьма продуктивной фазой как для московского градостроительства, так и для системы управления градостроительным процессом. В 1813 году вновь, как и в 1775-ом и «подобно» Каменному приказу был создан «чрезвычайный» орган для руководства реконструкцией - Комиссия для строений в Москве, состоявшая из штата чиновников и Чертёжной². 0 высоком статусе комиссии свидетельствует то, что председательствовали в ней московские военные генерал-губернаторы (рис. 5). Первый руководитель Чертёжной С.С. Кесарино, которого П.В. Сытин назвал «душой перепланировки Москвы» (скончался в 1817 году), составил концепцию реконструкции, а к 1817 году был готов генеральный план восстановления города [10, с. 49-66, 71, 78].

С 1814-го и до своей смерти в 1834 году Архитектурное отделение Чертёжной возглавлял О.И. Бове, ставший по сути главным архитектором города. По штату на него были возложены утверждение фасадов обывательских домов, наблюдение за строительством, проектирование общественных пространств, а также важных публичных и государственных зданий. По мнению историков архитектуры, период 1813-1834 годов был одним из самых плодотворных в истории московского градостроительства [11, с. 157; 12, с. 296]. Создание специальных органов управления, внимание императора Александра I, поддержка московских генерал-губернаторов,

${ }^{2}$ ПСЗ. - Собр. 1-е. - СПб., 1830. - Т.32. - № 25377, № 25378. - С. 559-561. 
активная деятельность 0.И. Бове, стоявшего во главе архитектурно-градостроительных преобразований и безусловно обладавшего целостным градостроительным видением города, принятие концепции и генерального плана реконструкции, организация типового проектирования фасадов для быстрого восстановления зданий, финансовые меры - всё это сложилось в комплексную систему управления, которая в короткий срок позволила провести восстановление города, обеспечив при этом целостность его архитектурного облика.

В 1834 году (после выполнения основного массива восстановительных работ и в связи с кончиной Бове) наступила фаза замедления градостроительной кампании, хотя в это время под руководством Д.М. Быковского, преемника О.И. Бове, проектировались и строились общественные объекты, ставшие градообразующими элементами Москвы. В 1843 году была упразднена Комиссия для строений в Москве, после чего управление градостроительным процессом вошло в фазу длительной стагнации. Штат архитекторов был передан в Управление IV округа путей сообщения, а их функции свелись к архитектурно-строительному контролю: выдаче разрешений и наблюдению за строительством.

Этап середины 1860-х - 1918-го годов в истории управления градостроительным процессом в Москве стоит особняком. Продолжительный по времени, он в то же время представляется наиболее однородным по своему содержанию. Бурный градостроительный рост, в отличие от предыдущих этапов, сочетался со стагнацией в области управления градостроительным процессом. Либеральные реформы Александра II, в первую очередь отмена крепостного права, реформы в области финансов, образования, городского самоуправления и др. создали основы для построения капиталистической экономики. Появление рынка рабочей силы вызвало рост промышленности и приток населения в города. Деловая жизнь Москвы стремительно ускорялась. Происходило быстрое приращивание городских территорий. Численность жителей в 1871 году в Москве составляла 590469 человек, в 1881-ом 753469, в 1897-ом - 978537, а к 1917-му превысила два миллиона. Москва в пореформенное время превратилась в торговопромышленный центр России, «в главное транспортное ядро, перевалочную базу, оптовый склад и железнодорожный узел всероссийского значения, средоточие деловой жизни и строительной деятельности» [13, с. 138-140]. Шло интенсивное застраивание свободных участков и уплотнение застройки центральных районов города за счёт заполнения усадебных владений, создание промышленных зон в логистических узлах вокруг железнодорожных вокзалов. Расширялась типология зданий: пассажи, банки, больницы, музеи, театры, учебные и благотворительные заведения; образовалась функциональная дифференциация центральных кварталов и целых секторов города по функциональному признаку (торгово-деловые, лечебные, научно-образовательные, промышленные).

«Городовое положение» 1870 года увеличило права городского самоуправления, но городские управы занима- лись главным образом вопросами экономики и городского благоустройства, не вдаваясь в сферу градостроительной политики. Строительная деятельность в Москве в пореформенный период регулировалась Строительным отделением Московского губернского правления и Строительным отделением Московской городской управы, которые имели сходные обязанности. В штате Строительных отделений числились гражданские инженеры и архитекторы. Как и в середине столетия, их функции фактически ограничивались архитектурностроительным контролем. Пореформенная Москва не имела единого плана развития; в условиях отсутствия запроса на целостное видение города не появилось и ярко-выраженного архитектора-«демиурга». Таким образом, развитие города происходило под влиянием экономических процессов, без участия направляющей силы единого административного руководства. Главным фактором градостроительных изменений стала внутренняя динамика развития города.

Пятый этап эволюции управления градостроительным процессом - 1918-1945 годы. В 1918 году, вскоре после 0ктябрьской революции и прихода к власти большевистского правительства, столица новой социалистической республики была перенесена в Москву. Эта дата стала переломным моментом, изменившим парадигму развития города на следующее столетие. Москве было предназначено стать не только административной столицей государства, но и символом мировой пролетарской революции для всего человечества. Фаза 1918-1930 годов была подготовительной, переходной к новому всплеску активности управления. В течение этого

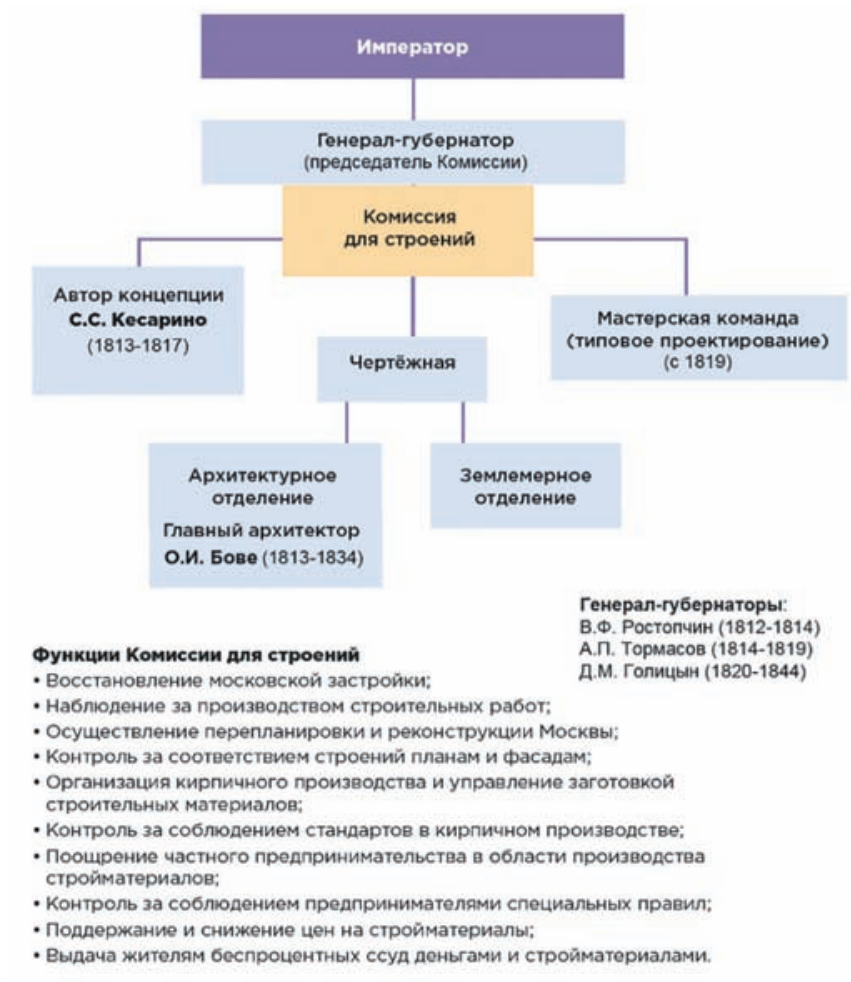

Рис. 5. Схема управления архитектурно-градостроительным процессом Москвы в 1813-1843 годы 
десятилетия градостроительная деятельность переживала стагнацию по причине экономических сложностей. То же можно сказать и об управлении градостроительным процессом: оно ограничивалось выдачей разрешений и наблюдением за строительством службой гражданских архитекторов, затем гражданских инженеров подобно тому, как это происходило в дореволюционный период. Тем не менее в это время происходило теоретическое переосмысление путей развития столицы. За короткое время было подготовлено несколько генеральных планов Москвы, которые не нашли практического применения, но послужили основой для разработок 1930-х годов: «Новая Москва» А.В. Щусева, «Большая Москва» и др.

1930-1935 годы стали очередной активной фазой эволюции управления градостроительным процессом. Определили её начало приход к власти И.В. Сталина, коллективизация крестьянства и начало пятилетки индустриализации (19281932), в результате которой крестьянские массы хлынули в большие города. Население Москвы в начале 1930-х годов увеличилось на миллион и превысило 3660000 человек [14, с. 93]. Для превращения Москвы в передовую столицу страны и «всего мирового пролетариата» ей требовалась радикальная реконструкция. Этот процесс возглавил Л.М. Каганович, в 1930 году назначенный секретарём Московского комитета ВКП(б). В течение 1930-1933 годов он провёл реформу организации управления развитием города, а за-

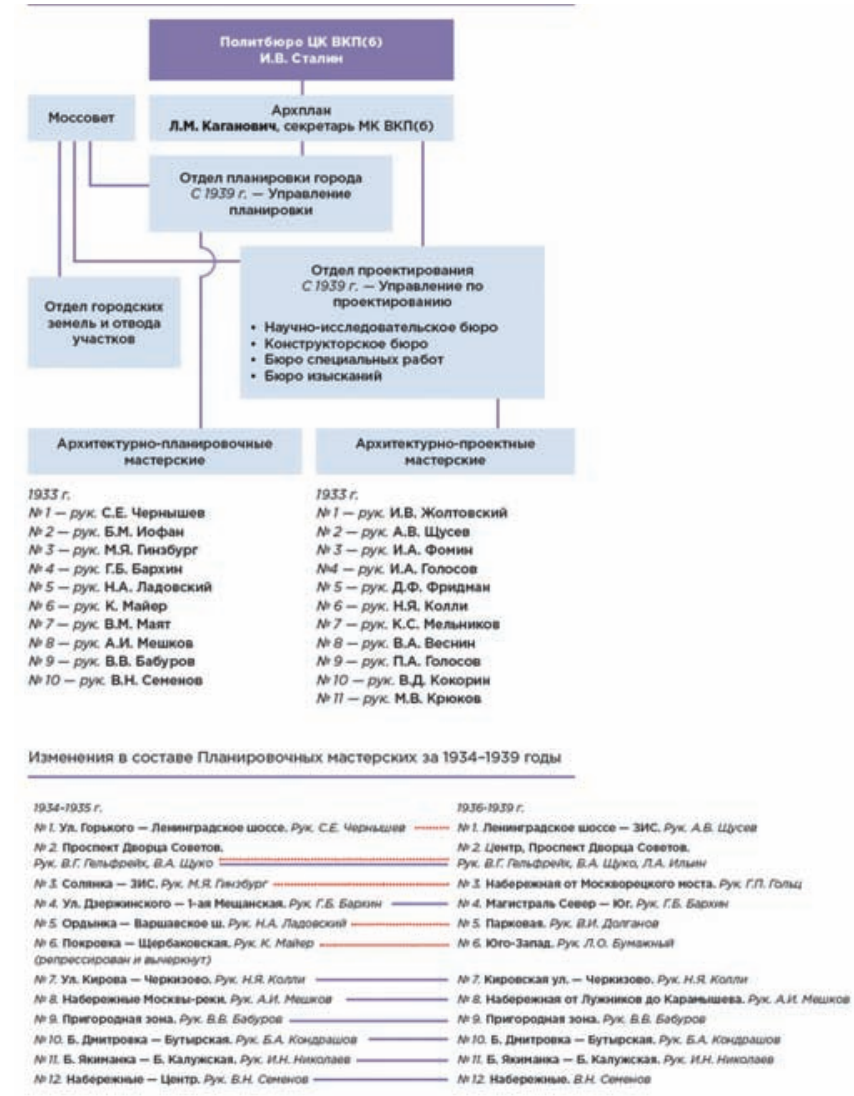

Рис. 6. Схема управления архитектурно-градостроительным процессом Москвы в 1933-1941 годы тем приступил к составлению программы реконструкции. Созданная Кагановичем структура органов управления градостроительным процессом походила на организацию управления послепожарным восстановлением Москвы 18131843 годов. Во главе «пирамиды» управления стояла высшая государственная воля политического вождя И.В. Сталина. На городском уровне был создан Архплан - надведомственная комиссия под председательством Кагановича. Она управляла штатом чиновников и архитекторами, объединёнными в две группы мастерских - планировочных и проектных (рис. 6). Проектирование генерального плана реконструкции возглавил маститый специалист в области градостроительства - главный архитектор Отдела планировки В.Н. Семёнов. В 1935 году его сменил известный градостроитель С.Е. Чернышев. Кагановичу удалось за два года (1933-1935) организовать подготовку программы реконструкции. Первоначально она называлась «Планировка города Москвы», затем «0сновы реконструкции города Москвы» и лишь в июле 1935 года, незадолго до утверждения правительством была переименована в «Генеральный план реконструкции города Москвы» ${ }^{3}$ [15]. В 1930-е годы в прессе, публичных выступлениях политических лидеров, архитекторов и строителей Генеральный план Москвы многократно был представлен «как величайшее достижение советского общества». В последующие годы этот подход стал одним из факторов, которые привели к абсолютизации генерального плана как неотъемлемого инструмента развития города. Фактически Генеральный план реконструкции Москвы 1935 года представлял собой одностраничную схему, сопровождаемую текстовым томом пояснительной записки $[16 ; 17]$. Главные элементы реконструкции, способствовавшие превращению Москвы в современный город, - строительство метро и обводнение Москвы, были осуществлены до утверждения Генерального плана реконструкции. После 1935 года интерес политического руководства страны к Генеральному плану Москвы ослабел, и 1935-1940 годы стали фазой замедления градостроительной активности и активности управления градостроительным процессом. Строительство в Москве в это время часто велось с отступлениями от Генерального плана [15]. В военное время (1941-1945) архитектурноградостроительная деятельность в Москве была временно приостановлена в связи с эвакуацией и концентрацией экономики на обеспечении военных нужд.

Шестой этап управления градостроительным процессом был относительно коротким (1945-1955) и прошёл в контексте послевоенного восстановления городов. Несмотря на непродолжительность, в нём можно выделить две фазы: 1945-1950 и 1951-1955 годы. И ту, и другую фазы можно считать активными в смысле строительства органов управления, однако они сильно различались по своим задачам и последствиям. В 1943-1944 годы

${ }^{3}$ ЦГА г. Москвы. Ф. Т-41. Оп. 1. Д. 25. Основы реконструкции гор. Москвы. 1935-1955. 
прошла реформа управления советским градостроительством. В 1944 году была официально введена должность главного архитектора Москвы. Он стал подчиняться напрямую городской администрации - Исполкому Моссовета. При главном архитекторе был образован Архитектурный совет - постоянный коллегиальный орган для обсуждения вопросов градостроительства и архитектурно-художественного облика зданий ${ }^{4}$. Главным архитектором города в 1945-1949 годы был Д.Н. Чечулин, апологет триумфального стиля советской архитектуры (рис. 7).

Следующая фаза (1950-1955) в процессе управления градостроительным развитием Москвы во многом обусловлена взаимодействием первого секретаря Московского комитета ВКП(б) Н.С. Хрущёва (с 1949 года) и главного архитектора Москвы А.В. Власова. Несмотря на то, что строительство в Москве все ещё продолжалось в парадигме, заданной Генеральным

${ }^{4}$ ЦГА г. Москвы. Ф. Р-534. 0п. 1. Д. 36. Л. 1-7. Положение об Управлении по делам архитектуры при Исполкоме Моссовета. 12.05.1944.

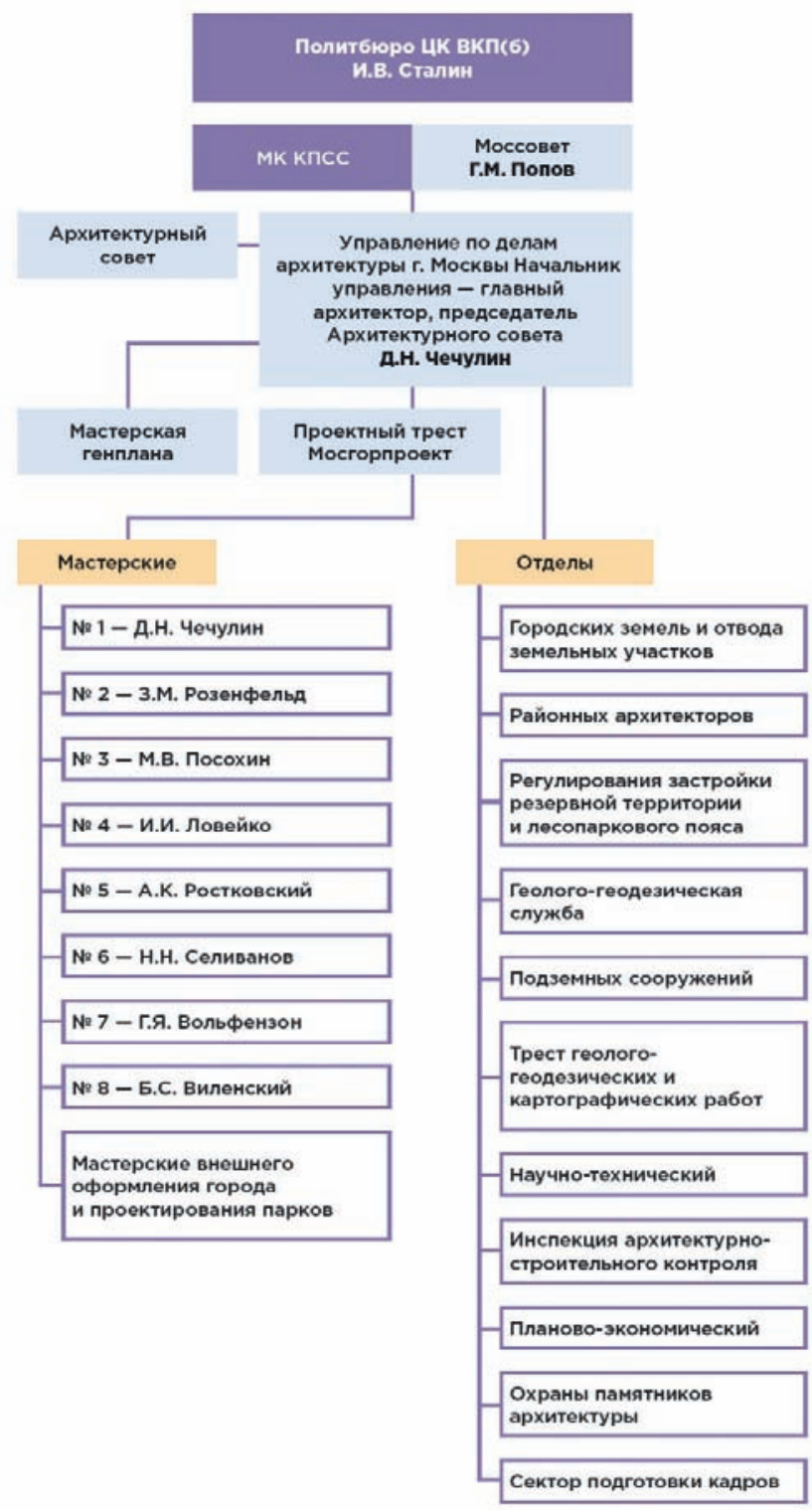

Рис. 7. Схема управления градостроительным процессом Москвы в 1945-1950 годы планом реконструкции 1935 года, в процессе управления вызревали серьёзные перемены. Н.С. Хрущёв и А.В. Власов в это время рассматривали пути удешевления строительства, применения индустриальных методов и типового проектирования. В 1950-1951 годы была проведена реорганизация системы управления проектным процессом, во время которой была создана структура АПУ и подчинённых ей проектных институтов, а также произошло объединение строительных организаций $[18 ; 17]$ (рис. 8). Эти преобразования создали предпосылки для перехода к следующему витку эволюции управления градостроительным процессом Москвы.

Седьмой этап эволюции управления градостроительным процессом Москвы (1955-1992) можно разделить на три фазы. Первая фаза (1955 - начало 1960-х) была активной и прошла при безусловном лидерстве Н.С. Хрущёва. В 1955 году он радикально изменил представление о перспективах развития архитектуры не только Москвы, но и всей страны. Оно опиралось на строительство массового дешёвого жилья для всех, демократизацию образа города, глобализацию и интеграцию в международный архитектурный процесс. Хрущёв стремился превратить Москву

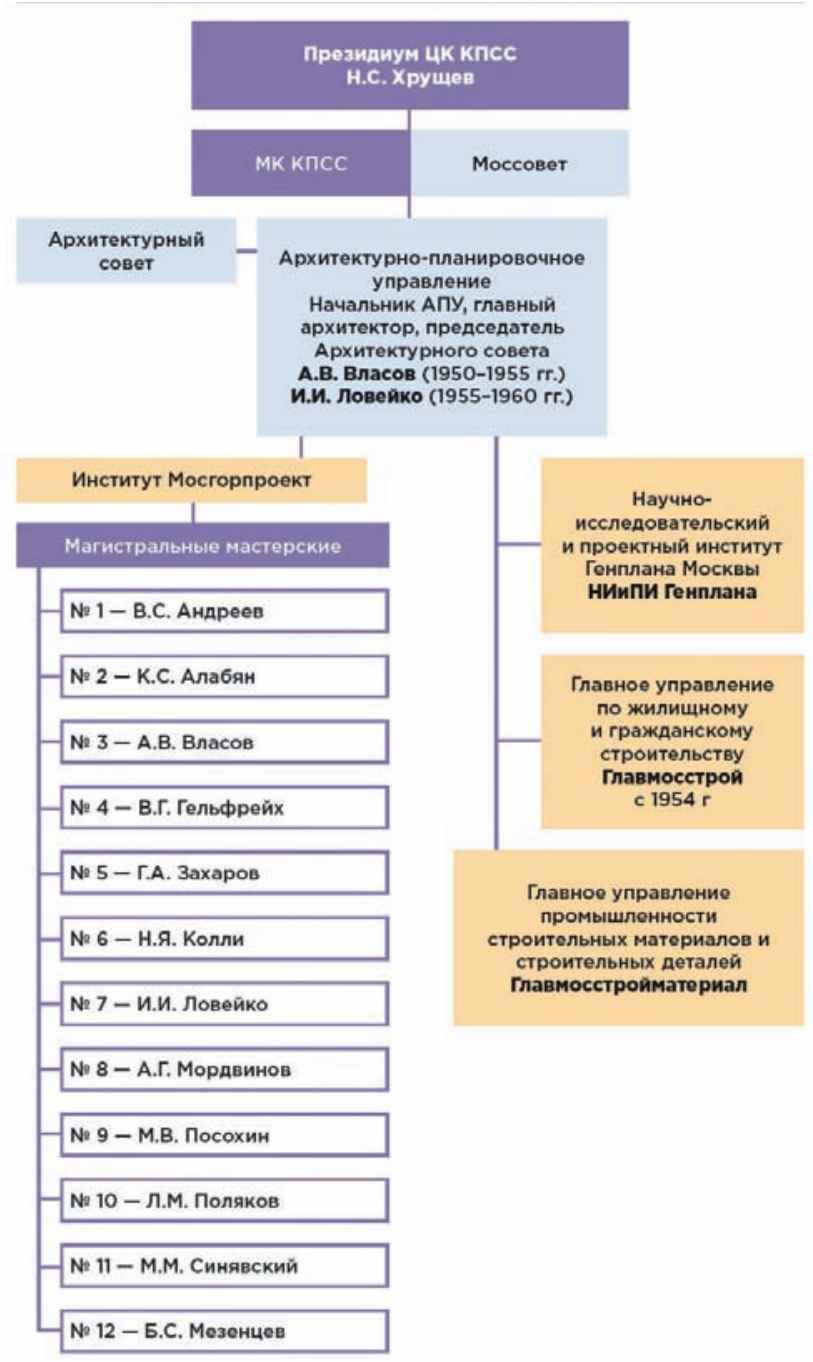

Рис. 8. Схема управления архитектурно-градостроительным процессом Москвы в 1953-1961 годы 
в современный европейский город. Для этого было необходимо не только строительство жилья, но и наличие знаковых проектов. Однако Хрущёв не доверял архитекторам и не раз обрушивал на них жёсткую публичную критику. Он был уверен, что «архитектора надо слушать, но не давать ему решать. Если архитекторы будут решать, погибла Москва, потому что они не считают деньги, не считаются со временем... власть в руки им не стоит давать» 5 . Этим объяснялся мелочный диктат Хрущёва в Москве даже по небольшим вопросам, таким как организация движения транспорта по центральным улицам, устройство новых подземных переходов и транспортных развязок. Одним из немногих архитекторов, кому удалось наиболее полно понять устремления Н.С. Хрущёва и обратить их в реальные проекты, был М.В. Посохин. В 1960 году он был назначен главным архитектором Москвы, заменив И.И. Ловейко (1955-1960). В 1960-1961 годы была проведена очередная реформа, которая привела к ещё большей концентрации управления градостроительным процессом в руках начальника ГлавАПУ - главного архитектора города (рис. 9). В это время М.В. Посохин не был начальником ГлавАПУ. Он совмещал посты председателя Государственного комитета по строительству и архитектуре при Госстрое СССР, министра и главного архитектора Москвы ${ }^{6}$.

Следующая фаза управления градостроительным процессом (середина 1960-х - 1980-е) также была активной.

${ }^{5}$ ЦГА г. Москвы. Ф. П-4. 0п. 124. Д. 9. Л. 46-69. Стенограмма беседы товарища Н.С. Хрущёва с руководителями Московского Совета по вопросам градостроительства. 26 мая 1962 г. Опубл. в: Архитектора надо слушать, но не давать ему решать // Историче-ский архив, 2012, №4, С. 35-62. Режим доступа: http://istmat.info/node/26312.

6 РГАЛИ. Ф.2466. Оп. 4. Д.143; 0п.9. Д.31; Ф.2916. 0п.3. Д.393.

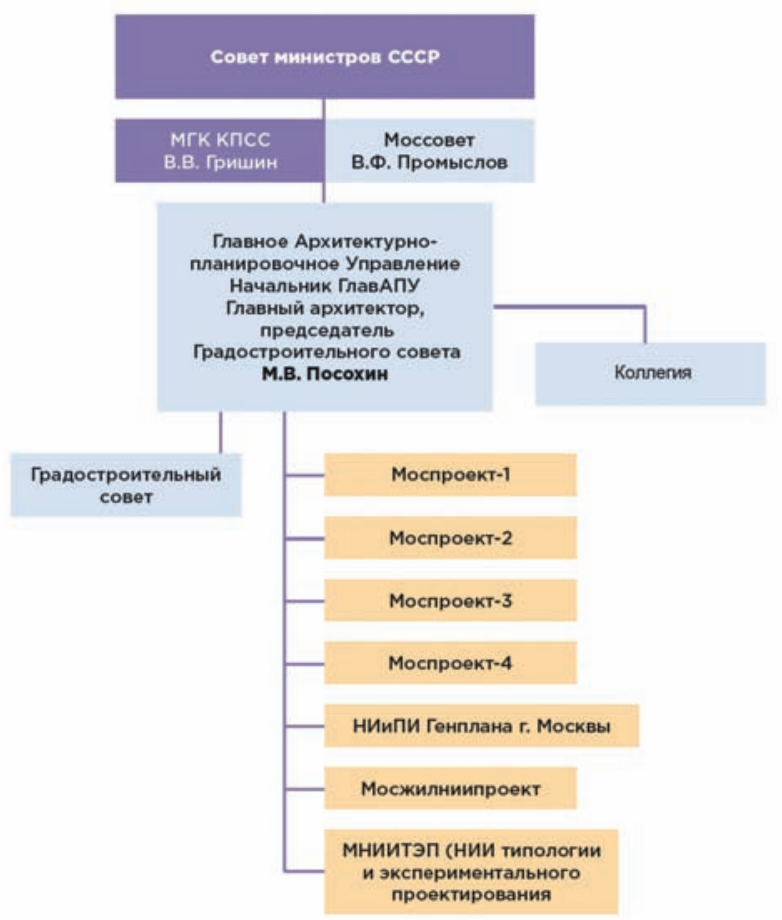

Рис. 9. Схема управления архитектурно-градостроительным процессом Москвы в 1960-1980-е годы
Она началась с устранением Н.С. Хрущёва от власти в 1964 году. Новый руководитель страны Л.И. Брежнев в отличие от своих предшественников не проявлял интереса к градостроительным делам кроме тех, которые могли иметь политическое значение (визиты иностранных политических деятелей, международные фестивали, Олимпиада-1980 и др.). Важные решения, касающиеся планировки Москвы как административной столицы государства, по-прежнему исходили от ЦК КПСС и Совета Министров СССР, но градостроительную политику Москвы в 1960-1970-е годы вершили московские власти: секретарь МГК КПСС В.В. Гришин, председатель Исполкома Моссовета В.Ф. Промыслов и главный архитектор М.В. Посохин. После 1967 года, когда М.В. Посохин вернулся на должность начальника ГлавАПУ, он полностью доминировал в московском градостроительном пространстве, сконцентрировав в одних руках управление огромным комплексом проектных институтов и в то же время оставаясь руководителем всех важнейших градостроительных и архитектурных проектов: Нового Арбата, здания СЭВ, олимпийских объектов. Он же возглавил разработку генерального плана развития Москвы. С середины 1960-х годов работа над генеральными планами стала одной из центральных задач ГлавАПУ. Подготовка Генерального плана развития Москвы 1971 года началась в 1960-е и велась несколькими проектными институтами и управлениями ГлавАПУ. К 1971 году Генплан был представлен в виде десятков томов пояснительных записок и детальных чертежей. Предполагалось, что он станет образцом для развития всех советских городов в начале XXI века. План был рассчитан ориентировочно до 1985 год с прогнозом по 2000-ый. Его целью было отразить значение Москвы как крупнейшего административно-политического, промышленного, научного и культурного центра, в архитектурном облике которого «должны найти яркое отражение прогрессивные идеи, социальный и научный прогресс Советского государства» [19, с. 126]. Генеральный план развития Москвы 1971 года сразу же показал свою нежизнеспособность. С одной стороны, реальное развитие города и рост населения опережали положения Генплана, с другой - такие затратные предложения, как создание полицентричного города, быстрое развитие метро, строительство Третьего транспортного кольца оказались невыполнимыми в условиях советской экономической системы.

В начале 1980-х годов управление градостроительным процессом вступило в фазу стагнации, которая закончилась в 1991 году одновременно с крахом социалистической системы. Для правления Л.И. Брежнева и его преемников были характерны разрастание бюрократического аппарата и постоянная деградация экономики. «Застойность» народного хозяйства экстраполировалась на архитектуру и градостроительство: «медлительность эволюции» отделила их от динамизма процессов, свойственных западной архитектуре; «мелочная бюрократическая регламентация» препятствовала «поискам и развитию новых направлений»; «подчинённость технологии», установленная во время хрущёвского периода, «лишала строительный 
комплекс побуждений к развитию, поощряла инертность» отсталой базы массового строительства [19, с. 408]. Управление шло по пути усложнения бюрократической структуры и разрастания архитектурно-строительного комплекса. К началу 1980-х годов присоединение новых территорий и постоянный рост населения превратили Москву в огромный мегаполис, для решения инфраструктурных, транспортных и градостроительных проблем которого была создана громоздкая и малоэффективная иерархия проектных и планировочныхуправлений и научно-исследовательских институтов, в которой архитекторы и планировщики занимали низшую ступень. Во главе этой пирамиды стоял главный архитектор с широкими полномочиями и правом принятия решений. 0 н же был руководителем большинства определявших лицо города архитектурных проектов, то есть по сути превратился в единоличного лидера архитектурно-градостроительного процесса. Кризисные явления осознавал Г.В. Макаревич, заменивший в 1980 году М.В. Посохина на посту главного архитектора Москвы. Он искал пути преодоления кризиса в реорганизации системы ГлавАПУ и в усложнении системы управления архитектурно-градостроительной отраслью ${ }^{7}$. Момент перехода к новой социально-экономической формации (конец 1980-х -1992-й) сопоставим с послереволюционным десятилетием начала XX века: те же экономические сложности, попытки найти новые подходы к планированию городского развития и те же организационные проблемы. В течение 1991-1993 годов произошла революционная трансформация государственного управления градостроительным процессом. 28 ноября 1991 года был образован Комитет по архитектуре и градостроительству (Москомархитектура). По утверждённому тогда же Временному положению о Москомархитектуре, председатель комитета назначался одновременно главным архитектором и председателем Архитектурного совета. Комитет был подчинён вице-мэру Москвы. От прежнего состава в нём остались три управления: планировки и застройки, архитектурно-градостроительного контроля и проектных организаций ${ }^{8}$. После преобразований 1991-1992 годов управление градостроительным процессом вошло в новый, постсоветский этап.

Анализ динамики управления градостроительным процессом Москвы на протяжении почти трёх столетий - с момента переноса столицы в Санкт-Петербург в 1713-1714 годы до возвращения ей столичного статуса в 1918-ом и затем до превращения в столицу СССР и затем - Российской Федерации (1991), показывает, что эволюция управления градостроительным процессом не являлась поступательным движением вперёд. Она, как правило, происходила циклично, в форме кампаний: фазы «активной» управленческой деятельности чередовались с «пассивными» фазами стагнации. Алгоритм управления,

\footnotetext{
${ }^{7}$ ЦГА г. Москвы. Ф. Л-279. 0п. 1. Д. 156. Л. 42-47.

${ }^{8}$ Распоряжение вице-мэра г. Москвы от 28.11.1991 № 368-РВМ «0б образовании ко-митета по архитектуре и градостроительству г. Москвы (Москомархитектуры) и лик-видации главного управления архитектуры и градостроительства (Главмосархитекту-ры)». - URL: http://www.businesspravo. ru/Docum/DocumShow_DocumID_143457_DocumIsPrint_Yes_Page_.html
}

сформировавшийся в XVIII столетии, с некоторыми вариациями повторялся на каждом последующем этапе: в ответ на вызовы, ухудшавшие градостроительную ситуацию, возникал запрос от высшей государственной власти на быстрое восстановление, создавались специальные органы управления градостроительством, разрабатывался генеральный план реконструкции; у каждой «градостроительной кампании» было своё лицо или свой союз власти и архитектора: императрица Елизавета Петровна и Д.В. Ухтомский; Л.М. Каганович; Н.С. Хрущёв и А.В. Власов; М.В. Посохин. Не всегда управленческие действия приводили к значительным фактическим градостроительным изменениям; происходившие изменения не имеют однозначной оценки с позиций сегодняшнего дня. Тем не менее очевидно, что наиболее плодотворными в градостроительной истории Москвы оказывались те моменты, когда удавалось организовать «синергическое» взаимодействие всех звеньев системы управления вокруг градостроительной повестки, предложенной харизматичным лидером-«демиургом» - архитектором или государственным деятелем - с градостроительным видением столицы.

\section{Лuтература}

1. Саваренская, Т.Ф. История градостроительного искусства. Поздний феодализм и капитализм : учеб. для архит. спец. вузов / Т.Ф. Саваренская, Д.О. Швидковский, Ф.А. Петров. - М. : Стройиздат, 1989 - 390 с.

2. Градостроительство России середины XIX - начала XX века: общ. характеристика и теорет. проблемы. В 3 книгах. / Под общ.ред. Е.И. Кириченко и др.- Книга 3 «Столицы и провинция». - М. : Прогресс-Традиция, 2010. - 612 с.

3. Ткаченко, С.Б. Один век московского градостроительства. Кн. 1-2 / С.Б. Ткаченко. - М. : Прогресс-Традиция, 2019.

4. Терминологический словарь по строительству на 12 языках (рус., болг., венг., исп., серб.-хорв., чеш., англ., фр.) / ГСЭВ. Постоян. комис. по стр-ву; Сост. М. Е. Беленький и др. - М. : Рус. яз., 1986. - 861 с.

5. Сытин, П.В. История планировки и застройки Москвы. Материалы и исследования. Том I (1147-1762 годы) / П.В. Сытин. - М., 1950.

6. Мурзин-Гундоров, В.В. Дмитрий Ухтомский / В.В. Мурзин-Гундоров. - М. : Изд. дом Руденцовых, 2012 - 343 с.

7. Клименко, Ю.Г. Творчество архитектора Н. Леграна, 1738/41 -1791 гг. : дис. ... кандидата архитектуры : 18.00.01. - Москва, 2000. - 253 с.

8. Клименко, Ю.Г. Пространство города эпохи Просвещения в первом проектном плане Москвы 1775 г. / Ю.Г. Клименко // Пространства России. - 2013. - № 4 (14). - С. 136-145.

9. Смирнова, А.Г. Градостроительство и органы московского городского управления (60-е гг. XVIII в. - 30-е гг. XIX в.) : дис. ... кандидата исторических наук : 07.00.02 / Рос. гос. гуманитар. ун-т. - М., 2002. - 345 с.

10. Белов, А.В. Создание регулярного города во второй половине XVIII в. Первый реализованный план «генеральной 
реконструкции» Москвы. Концепция, замыслы, результаты / А.В. Белов // Вестник славянских культур. - 2018. - Т. 49. - С. 293-304.

11. Сытин, П.В. Пожар Москвы в 1812 г. и строительство города в течение 50 лет (1812-1862) / П.В. Сытин; под общей редакцией И.С. Гомановского. - М. : Московский рабочий, 1972. -400 c.

12. Памятники архитектуры Москвы: Кремль. Китай-город. Центральные площади. / Ю. И. Аренкова, М.И.Домшлак, В. Я. Либсон [и др.]. - М. : Искусство, 1982. - 503 с.

13. Покровская 3.К. Осип Бове / З.К. Покровская. - М. : Стройиздат, 1999. - 349 с.

14. СССР в цифрах. - М. : Союзоргучёт, 1934. - 226 с.

15. Кузнецов С.О. Власть и Генеральный план реконструкции Москвы (1931 - начало 1950-х гг.) [Электронный ресурс] // Architecture and Modern Information Technologies. - 2019. - № 4 (49). - С. 28-46. - Режим доступа: https://marhi.ru/ AMIT/2019/4kvart19/PDF/02_kuznetsov.pdf (дата обращения 20.02.2020).

16. Старостенко Ю.Д. «Мы должны вести твёрдый план»: к истории рассмотрения первого варианта Генерального плана реконструкции Москвы в июле 1934 года // Academia. Архитектура и строительство. - 2019. - № 2. - С. 92-99.

17. Кузнецов С.О. Н.С. Хрущёв и борьба с излишествами в советской архитектуре (1949-1954 годы) // Academia. Архитектура и строительство. - 2019. - № 3. - С. 5-10.

18. Пекарева Н.А. М.В. Посохин М.В. Народный архитектор СССР . - М. : Советский художник, 1985. - 240 с.

19. Иконников, А.В. Архитектура XX века: Утопии и реальность : Изд. в 2 т. / А.В. Иконников. - М. : Прогресс-Традиция, 2001.

20. Клименко, С.В. Архитектурная деятельность И. Ф. Мичурина. 1720-1750-е годы : дис. ... кандидата архитектуры : 18.00.01 / Моск. архитектур. ин-т. - М., 2002. - 290 с.

\section{References}

1. Savarenskaya T.F., Shvidkovskii D.0., Petrov. F.A. Istoriya gradostroitel'nogo iskusstva. Pozdnii feodalizm i kapitalizm [History of urban art. Late feudalism and capitalism: ucheb. dlya arkhit. spets. vuzov. Moscow, Stroiizdat Publ. 1989, 390 p.

2. Kirichenko E.I. [et al.] (ed) Gradostroitel'stvo Rossii serediny XIX - nachala XX veka : Obshch. kharakteristika i teoret. problemy [Urban planning in Russia mid-XIX - early XX centuries: General characteristics and theoretical problems]. V 3 knigakh. Kn 3 «Stolitsy i provintsiya» [Capitals and province]. Moscow, Progress-Traditsiya Publ., 2010.

3. Tkachenko S.B. Odin vek moskovskogo gradostroitel'stva [One Century of Moscow Urban Planning]. Kn. 1-2. Moscow, Progress-Traditsiya Publ., 2019.

4. Terminologicheskii slovar' po stroitel'stvu na 12 yazykakh (rus., bolg., veng., isp., serb.-khorv., chesh., angl., fr.) [The terminological dictionary от construction, in 12 languages (Russian, Bulgarian, Hungarian, Spanish, Serbian-Croatian, Czech, English, French)]. Moscow, Rus. Yaz. Publ., 1986, 861 p.
5. Sytin P.V. Istoriya planirovki i zastroiki Moskvy. Materialy $i$ issledovaniya. Tom I (1147-1762 gody) [The history of the planning and development of Moscow. Materials and research. Volume I (1147-1762)]. Moscow, 1950.

6. Murzin-Gundorov V.V. Dmitrii Ukhtomskii [Dmitry Ukhtomsky]. Moscow, Izd. dom Rudentsovykh Publ., 2012, 343 p.

7. Klimenko Yu.G. Tvorchestvo arkhitektora N. Legrana, 1738/41-1791 gg. [Creativity of the architect N. Legrand, 1738/41-1791]: dis. ... kand. arkh. Moscow, 2000.

8. Klimenko Yu.G. Prostranstvo goroda epokhi Prosveshcheniya v pervom proektnom plane Moskvy $1775 \mathrm{~g}$. [The space of the city of the Enlightenment in the first project plan of Moscow 1775]. Prostranstva Rossii [Spaces of Russia], 2013, no. 4 (14), pp. 136-145.

9. Smirnova A.G. Gradostroitel'stvo i organy moskovskogo gorodskogo upravleniya (60-e gg. XVIII v. - 30-e gg. XIX v.) [Urban planning and the Moscow city government (60s. XVIII century - 30s. XIX century.] : dis. ... kand. ist. nauk. Moscow, 2002, pp. 98, 99, 147-151.

10. Belov A.V. Sozdanie regulyarnogo goroda vo vtoroi polovine XVIII v. Pervyi realizovannyi plan «general'noi rekonstruktsii» Moskvy. Kontseptsiya, zamysly, rezul'taty [The creation of a regular city in the second half of the XVIII century. The first implemented plan for the "general reconstruction" of Moscow. Concept, thoughts, results]. Vestnik slavyanskikh kul'tur [Bulletin of Slavic cultures], 2018, Vol. 49, pp. 293-304.

11. Sytin P.V. Pozhar Moskvy v 1812 g. i stroitel'stvo goroda v techenie 50let (1812-1862 gg.) [The fire of Moscow in 1812 and the construction of the city for 50 years (1812-1862)]. Moscow, 1952.

12. Arenkova Yu.I., Domshlak M.I., Libson V.Ya. [et al.]. Pamyatniki arkhitektury Moskvy: Kreml'. Kitai-gorod. Tsentral'nye ploshchadi [Monuments of Moscow architecture: the Kremlin. Kitai-gorod. Central squares]. M.V. Posokhin (ed.). Moscow, Iskusstvo Publ., 1982.

13. Pokrovskaya Z.K. Osip Bove [Osip Beauvais]. Moscow, Stroiizdat Publ., 1999.

14. SSSR $v$ tsifrakh [USSR in numbers]. - Moscow, Soyuzorguchet Publ., 1934, 226 p.

15. Kuznetsov S.0. Vlast' i General'nyi plan rekonstruktsii Moskvy (1931 - nachalo 1950-kh gg.) [Power and master plan for the reconstruction of Moscow (1931 - early 1950s)]. Architecture and Modern Information Technologies, 2019, no. 4 (49), pp. 28-46. URL: https://marhi.ru/AMIT/2019/4kvart19/ PDF/02_kuznetsov.pdf (Accessed 20.02.2020)

16. Starostenko Yu.D. «My dolzhny vesti tverdyi plan»: $k$ istorii rassmotreniya pervogo varianta General'nogo plana rekonstruktsii Moskvy v iyule 1934 goda ["We must lead a solid plan": to the history of consideration of the first version of the General Plan for the reconstruction of Moscow in July 1934 ]. Academia. Arkhitektura i stroitel'stvo [Academia. Architecture and construction], 2019, no. 2, pp. 92-99.

17. Kuznetsov S.0. N.S. Khrushchev i bor'ba s izlishestvami v sovetskoi arkhitekture (1949-1954 gody) [N.S. Khrushchev 
and the struggle against excesses in Soviet architecture (1949-1954)]. Academia. Arkhitektura i stroitel'stvo [Academia. Architecture and construction], 2019, no. 3, pp. 5-10.

18. Pekareva N.A. Posokhin M.V. Narodnyi arkhitektor SSSR M.V. [Posokhin M.V. People's architect of the USSR]. Moscow, Soviet Artist Publ., 1985, 240 p.
19. Ikonnikov A.V. Arkhitektura XX veka. Utopii i real'nost' [0th Century Architecture: Utopia and Reality]. In 2 vol. Vol. 1. Moscow, Progress-Traditsiya Publ., 2001.

20. Klimenko S.V. Arkhitekturnaya deyatel'nost' I.F. Michurina. 1720-1750-e gody [Architectural activity of I.F. Michurin. 1720-1750s]: dis ... kand. arkh. Moscow, 2002, 290 p.

Кузнецов Сергей Олегович (Москва). Главный архитектор города Москвы, первый заместитель председателя Комитета по архитектуре и градостроительству города Москвы (125047, Москва, Триумфальная площадь, 1. Москомархитектура). Эл.почта: KuznetsovS0@mos.ru.

Kuznetsov Sergey Olegovich (Moscow). Chief Architect of Moscow, First Deputy Chairman of the Committee for Architecture and Urban Planning of Moscow (1 Triumfalnaya Square, Moscow, 125047. Moskomarkhitektura). E-mail: KuznetsovS0@mos.ru. 